\title{
Indium In 111-DOTA-Biotin
}

National Cancer Institute

\section{Source}

National Cancer Institute. Indium In 111-DOTA-Biotin. NCI Thesaurus. Code C2495.

A radioconjug ate of biotin conjug ated with the bifunctional, macrocyclic chelating agent tetra-azacyclododecanetetra-acetic acid (DOTA) and labeled with indium In 111 (In-111). Biotin is a water-soluble B-complex vitamin, present in minute amounts in every living cell, while its level in cancerous tissue is higher than that of normal tissue. In 111-DOTA-Biotin could be used in 3-step pre-targeting radioimmunotherapy that employs tumor targeting antibody conjug ated with streptavidin, the natural ligand of biotin. 